\title{
Role of guinea-pig sperm autoantigens in sperm binding to the zona pellucida and oocyte penetration*
}

\author{
G. Munoz de Vera†, B. Marquant-Le Guienneł, M. De Almeida and \\ G. A. Voisin \\ Centre d'Immuno-Pathologie Expérimentale de l'INSERM (U 23), du CNRS (LA 289) et de \\ l'Association Claude-Bernard (C 12), Hôpital St-Antoine, 184, rue du Fg St-Antoine, \\ 75571 Paris Cedex 12, France
}

\begin{abstract}
Summary. In vitro, binding of acrosome-reacted spermatozoa to the zona pellucida of mature guinea-pig oocytes was inhibited by guinea-pig sperm anti-T IgG and antibodies. Anti-P IgG antibodies prevented oocyte penetration without interfering with spermzona binding. The fusion of acrosome-reacted spermatozoa with zona-free oocytes was prevented by anti-T IgG and it was diminished by anti-P IgG. In the same conditions anti-S antibodies had no effect in these in-vitro fertilization events. Immunization of female guinea-pigs with $\mathbf{P}$ antigen resulted in a significant decrease of the number of tubal cleaved eggs. $T$ antigens were less clearly implicated in fertilization in vivo. This study provides evidence that well characterized autoantigenic molecules of guinea-pig spermatozoa are involved in fertilization events.
\end{abstract}

\section{Introduction}

The fertilization process implies several events such as sperm capacitation, the acrosome reaction, attachment to the zona pellucida and its penetration and finally sperm and egg fusion. Little is known about the molecular mechanisms involved in these events and different ways have been used to investigate these phenomena in vivo or in vitro. The use of antibodies against sperm proteins has been one of the ways to recognize the sperm components involved in fertilization. There is some evidence in guinea-pigs of different effects of antibodies in these events. Tung, Okada \& Yanagimachi (1980) have observed an inhibition of the acrosome reaction in the presence of antibodies against whole guinea-pig spermatozoa. The same antibody preparation (Yanagimachi, Okada \& Tung, 1981) prevented in-vitro fertilization of guinea-pig oocytes.

Three antigens have been described as autoantigens for guinea-pigs, S, P and T (Voisin \& Toullet, 1968). By immunofluorescence (Toullet, Voisin \& Nemirovsky, 1973) and an immunoperoxidase technique associated with electron microscopy studies (Le Bouteiller, Toullet, Righenzi \& Voisin, 1979), these three autoantigens have been localized: $S$ and $\mathbf{P}$ are present in the acrosomal matrix and acrosomal membranes, while $\mathrm{T}$ is present on the cytoplasmic membrane of spermatozoa as well as on the outer acrosome membrane. These antigens have been well studied in relation to their physico-chemical and immunopathological characteristics (Toullet \& Voisin, 1976; Toullet, Chadenier, Maillard \& Voisin, 1985). We are now focusing our research on the biological role of these autoantigens in the fertilization process. Marquant-Le Guienne \& De Almeida (1986) have

\footnotetext{
* Reprint requests to Dr M. De Almeida.

+ Present address: Departement des Organismes, Université Simon Bolivar, Caracas, Venezuela.

$\ddagger$ Present address: Laboratoire pour le Contrôle des Reproducteurs. 13, rue Jouët, 94703 Maisons-Alfort, France.
} 
demonstrated that anti-T antibodies inhibited the acrosome reaction of guinea-pig epididymal spermatozoa. Anti-S antibodies also inhibited, but to a lesser degree, the acrosome reaction. Because $\mathrm{S}, \mathrm{P}$ and $\mathrm{T}$ antigens are still present on acrosome-reacted spermatozoa it was presumed that these autoantigens could have other functions in fertilization events.

In the present study the effects of anti-S, anti-P and anti-T autoantibodies on the binding to the zona pellucida and on the penetration of intact and zona-free guinea-pig oocytes by acrosomereacted guinea-pig spermatozoa were examined in vitro.

\section{Materials and Methods}

The immunization procedure and the preparation of the immunoglobulins and Fab fragments were as described by Marquant-Le Guienne \& De Almeida (1986). IgG and Fab concentrations were expressed as protein per ml (Bradford, 1976).

Sera and IgG immune tests. Enzyme-linked immunoabsorbent assay (ELISA) was performed as previously described (Marquant-Le Guienne \& De Almeida, 1986). Briefly, test samples were incubated in microtitre plate wells coated with the target antigen. Peroxidase-labelled rabbit antiguinea-pig IgG (Miles-Yeda Ltd, Rehovot 76 236, Israel) was the second step reagent. Antibody fixation was detected by adding the enzyme substrate (ABTS dye solution; Boehringer Mannheim, 38240 Meylan, France). The rate of colour development was quantified in an automatic ELISA microtitre reader (Dynatech MR 580, Dynatech SARL, 94613, Rungis, France).

Antibody activity is expressed as ELISA units, one unit corresponding to the protein concentration that gives twice the absorbance of the negative control (guinea-pig immune serum unrelated to sperm antigens).

Spermagglutination and complement-dependent sperm immobilization were performed as described by Toullet \& Voisin (1974) except that microplates with flat bottomed wells were used and the reactions were read in an inverted microscope.

Recovery and preparation of oocytes. Because of the small number of oocytes naturally ovulated by guinea-pigs (2-4), we tried to induce superovulation in these females. For this, mature Hartley female guinea pigs were examined daily for the vaginal closure membrane. At least two oestrous cycles were recorded before starting hormonal treatment. Several schedules of injection of PMSG (Chronogest, Intervet S.A., 49000 Angers, France), PGF-2 $\alpha$ (Dinolytic, Upjohn, 92081 Paris La Défense, France) and hCG (Pregnyl, Organon, 93204 Saint-Denis, France) were tested. However, because superovulation was not achieved, guinea-pig oocytes were then collected from the ovaries after 3 intraperitoneal injections of 50 i.u. PMSG on Days 5, 6 and 7 of the cycle (Day $1=$ day of oestrus); 1 intramuscular injection of $1 \mathrm{mg}$ PGF-2 $\alpha$ on Day 9; and 100 i.u. hCG injected i.p. on Day 11. The largest follicles were punctured $72 \mathrm{~h}$ later and the cumulus-enclosed oocytes were collected in $\mathrm{BMOC}_{3}$ (Brinster Medium for Oocyte Culture; Gibco, France). The average number of mature oocytes recovered per female was $14 \pm 2$. Cumulus cells were dispersed by $1 \%$ hyaluronidase (bo"vine testes, type IV; Sigma, Mallet Chemicals SA, 95704 Roissy, France) for $5 \mathrm{~min}$ at $37^{\circ} \mathrm{C}$ followed by 3 washings. Zona-free oocytes were obtained by digestion of the zona pellucida with $0.2 \%$ pronase (45 PUK $/ \mathrm{mg}$, Calbiochem-Behring, 92190 Meudon, France) during $1 \mathrm{~min}$ at room temperature and immediately washed 3 times in $\mathrm{BMOC}_{3}$. Intact and zona-free oocytes were maintained in $\mathrm{BMOC}_{3}$ until insemination.

In-vitro treatment of guinea-pig spermatozoa by antibodies. Each cauda epididymidis was removed from mature Hartley guinea-pig males and punctured with a needle to free spermatozoa into PBS containing $0.3 \%$ BSA (Fraction V, Sigma). The sperm suspension was centrifuged at $600 \mathrm{~g}$ for $5 \mathrm{~min}$ and spermatozoa were resuspended in $\mathrm{Ca}^{2+}$-containing $\mathrm{BMOC}_{3}$ at a concentration 
of $10^{7} / \mathrm{ml}$. Drops of $100 \mu \mathrm{l}$ of this suspension were incubated at $37^{\circ} \mathrm{C}$ under mineral oil. After $18 \mathrm{~h}$ the spermatozoa had a vigorous motility and about $80 \%$ had undergone the acrosome reaction. Aliquants of $10 \mu \mathrm{l}$ acrosome-reacted spermatozoa and $90 \mu \mathrm{l}$ of the IgGs at different protein concentrations were incubated for $30 \mathrm{~min}$ at $37^{\circ} \mathrm{C}$ before oocytes were added. For each antigen two different preparations of specific IgG were tested and the results were pooled.

In-vitro fertilization. Guinea-pig oocytes were introduced into $100 \mu \mathrm{l}$ of antibody-treated sperm suspensions under mineral oil. The mixtures were incubated at $37^{\circ} \mathrm{C}$ under a $5 \% \mathrm{CO}_{2}$ in air atmosphere. At 3-4h after insemination the oocytes were washed, mounted on a microscope slide and moderately compressed under a coverslip. Sperm attachment to the zona pellucida and oocyte penetration were observed with a phase-contrast microscope. Detection of swollen sperm heads or pronuclei in unfixed guinea-pig oocytes was difficult due to the opacity of the cytoplasm. Sperm penetration was confirmed by staining the oocytes with acridine orange (Bertalanfly, 1962) or DAPI (4,5-diamino-2-phenylindole: Sigma) after digestion of the zona pellucida with $0 \cdot 1 \%$ pronase.

To detect an eventual effect of the antibodies on the surface of oocytes, these cells were incubated with anti-S, anti-P or anti-T antibodies for $30 \mathrm{~min}$ at $37^{\circ} \mathrm{C}$, washed and inseminated with untreated spermatozoa.

\section{Results}

\section{Immunological testing of anti-S, anti-P and anti-T IgGs}

The IgGs prepared from immune sera raised against $\mathbf{S}, \mathbf{P}$ and $\mathrm{T}$ autoantigens had high titres in ELISA technique with the corresponding antigens (Table 1). Anti-T IgG was also able to agglutinate and immobilize (in the presence of complement) the guinea-pig epididymal spermatozoa. After the acrosomal reaction the spermatozoa were no longer agglutinated by the same IgG. This allowed us to study the effect of different concentrations of these antibody preparations on in-vitro fertilization.

Effect of the antigens on the interaction between acrosome-reacted guinea-pig spermatozoa and zonaintact guinea-pig oocytes

Acrosome-reacted guinea-pig spermatozoa in $\mathrm{BMOC}_{3}$ only or in the presence of antiDNP-BGG IgG (control) bound firmly to the zona surface (Table 2). The lowest concentrations of

Table 1. Immunological testing of guinea-pig anti-S, -P and -T IgG with guinea-pig spermatozoa auto-antigens

\begin{tabular}{lrrcc}
\hline IgG & No. & ELISA $^{*}$ & Spermagglutination $\dagger$ & $\begin{array}{c}\text { Spermimmobilization } \\
\text { (C'-dependent) } \ddagger\end{array}$ \\
\hline Anti-S & 2 & 6400 & - & - \\
& 6 & 1600 & - & - \\
Anti-P & 1 & 12800 & - & - \\
& 2 & 12800 & - & 256 \\
Anti-T & 19 & 6400 & 64 & 512 \\
& 137 & 3200 & 64 & \\
\hline
\end{tabular}

* Last dilution giving an absorbance twice that of the negative control.

$\uparrow$ Last agglutinating dilution.

$\ddagger$ Last dilution giving $50 \%$ spermimmobilization. 
Table 2. Effect of anti-S, anti-P and anti-T IgGs on the interaction between acrosomereacted guinea-pig spermatozoa and zona-intact guinea-pig oocytes

\begin{tabular}{|c|c|c|c|c|}
\hline \multicolumn{2}{|c|}{ Sperm treatment } & \multirow{2}{*}{$\begin{array}{c}\text { Spermatozoa } \\
\text { bound to } \\
\text { zona }(n)\end{array}$} & \multirow{2}{*}{$\begin{array}{c}\text { Oocytes } \\
\text { examined } \\
(n)\end{array}$} & \multirow{2}{*}{$\begin{array}{c}\text { Oocytes } \\
\text { penetrated } \ddagger \\
(\%)\end{array}$} \\
\hline $\operatorname{IgG}$ & $\begin{array}{c}\text { Dose }(\mu \mathrm{g} / \mathrm{ml}) \\
(\text { E.U. })^{\dagger}\end{array}$ & & & \\
\hline Anti-S & $\begin{array}{l}500(312) \\
1000\end{array}$ & $\begin{array}{l}>100 \\
>100\end{array}$ & $\begin{array}{l}21 \\
12\end{array}$ & $\begin{array}{l}86 \cdot 1 \\
66 \cdot 6\end{array}$ \\
\hline Anti-P & $\begin{array}{c}63 \\
125 \\
250 \\
500(1190) \\
1000\end{array}$ & $\begin{array}{l}>100 \\
>100 \\
>100 \\
>100 \\
>100\end{array}$ & $\begin{array}{r}18 \\
8 \\
15 \\
14 \\
16\end{array}$ & $\begin{array}{l}77 \cdot 7 \\
75 \cdot 0 \\
60 \cdot 8 \\
14 \cdot 0^{*} \\
0 * *\end{array}$ \\
\hline Anti- $T$ & $\begin{array}{l}63 \\
125 \\
250 \\
500(625)\end{array}$ & $\begin{array}{r}25-50 \\
<25 \\
0 \\
0\end{array}$ & $\begin{array}{l}11 \\
19 \\
17 \\
19\end{array}$ & $\begin{array}{l}79 \cdot 3 \\
0^{* *} \\
0^{* *} \\
0^{* *}\end{array}$ \\
\hline Anti-DNP-BGG\& & $\begin{array}{r}63 \\
125 \\
250 \\
500 \\
1000\end{array}$ & $\begin{array}{l}>100 \\
>100 \\
>100 \\
>100 \\
>100\end{array}$ & $\begin{array}{r}16 \\
7 \\
10 \\
17 \\
15\end{array}$ & $\begin{array}{l}91 \cdot 6 \\
100 \\
100 \\
92 \cdot 4 \\
79 \cdot 4\end{array}$ \\
\hline None & - & $>100$ & 75 & $90 \cdot 9$ \\
\hline
\end{tabular}

Results are the mean of $2-5$ experiments.

$\dagger \operatorname{lgG}$ antibody activity is expressed as ELISA units (E.U.) as described in 'Materials and Methods'.

$¥$ At least one swollen sperm head per oocyte.

$\S$ Guinea-pig IgG anti-dinitrophenylated bovine gammaglobulin (control).

Significantly different from control values: ${ }^{*} 0.05>P>0.02 ;{ }^{* *} P<0.001$ ( $\chi^{2}$ test).

anti-T IgG tested $(63$ and $125 \mu \mathrm{g} / \mathrm{ml})$ strongly diminished this binding. A complete inhibition was observed with 250 and $500 \mu \mathrm{g} / \mathrm{ml}$ of the same IgG. Unbound spermatozoa retained good motility. Anti-S and anti-P IgGs did not interfere with sperm binding to the zona.

Over $90 \%$ of oocytes were penetrated by untreated or anti-DNP-BGG IgG-treated spermatozoa. Anti-S IgG had no significant effect on oocyte penetration, but penetration was prevented by $1 \mathrm{mg}$ anti-P IgG/ml and significantly reduced by 250 and $500 \mu \mathrm{g}$ anti-P $\mathrm{IgG} / \mathrm{ml}$. Spermatozoa treated with anti-T IgG $(\geqslant 125 \mu \mathrm{g} / \mathrm{ml})$ did not penetrate intact oocytes because they were unable to bind to zona pellucida.

In the presence of anti-T Fab fragments, sperm binding to the zona was prevented. The numbers of penetrated oocytes were reduced to $50 \%$ with $125 \mu \mathrm{g} / \mathrm{ml}$ and completely inhibited with $250 \mu \mathrm{g}$ anti-T Fab fragments/ml (data not shown).

Intact oocytes incubated with anti-S, anti-P or anti-T IgGs at $500 \mu \mathrm{g} / \mathrm{ml}$ were subsequently normally fertilized ( $80-100 \%$ penetration) by untreated acrosome-reacted spermatozoa.

Effect of anti-P and anti-T IgGs on the interaction between acrosome-reacted guinea-pig spermatozoa and zona-free guinea-pig oocytes

Because anti-P and anti-T IgGs were able to prevent the penetration of intact oocytes by acrosome-reacted spermatozoa either by inhibition of their binding to the zona (anti-T antibodies) or by some other mechanism (anti-P and anti-T antibodies), it became necessary to study the effects of these antibodies on gamete membrane interactions. For this, zona-free guinea-pig oocytes were inseminated with spermatozoa treated with anti-P and anti-T IgGs at concentrations shown to 
Table 3. Effect of anti-P and anti-T IgGs on the interaction between acrosome-reacted guinea-pig spermatozoa and zona-free guinea-pig oocytes

\begin{tabular}{|c|c|c|c|}
\hline \multicolumn{2}{|c|}{ Sperm treatment } & \multirow{2}{*}{$\begin{array}{l}\text { Oocytes } \\
\text { examined } \\
\qquad(n)\end{array}$} & \multirow{2}{*}{$\begin{array}{c}\text { Oocytes } \\
\text { penetrated } \ddagger \\
(\%)\end{array}$} \\
\hline IgG & $\begin{array}{c}\text { Dose }(\mu \mathrm{g} / \mathrm{ml}) \\
(\text { E.U. }) \dagger\end{array}$ & & \\
\hline Anti-P & $\begin{array}{l}500(1190) \\
1000\end{array}$ & $\begin{array}{l}15 \\
15\end{array}$ & $\begin{array}{l}73 \cdot 2 \\
53 \cdot 6^{*}\end{array}$ \\
\hline Anti-T & $\begin{array}{l}125 \\
250 \\
500(525)\end{array}$ & $\begin{array}{l}10 \\
11 \\
10\end{array}$ & $\begin{array}{l}58 \cdot 3 \\
45 \cdot 0^{*} \\
0^{* *}\end{array}$ \\
\hline Anti-DNP-BGG§ & $\begin{array}{l}125 \\
250 \\
500\end{array}$ & $\begin{array}{l}6 \\
6 \\
7\end{array}$ & $\begin{array}{l}100 \\
100 \\
100\end{array}$ \\
\hline None & - & 10 & 80.0 \\
\hline
\end{tabular}

Results are the mean of 2 experiments.

$\dagger$ IgG antibody activity is expressed as ELISA units (E.U.) as described in 'Materials and Methods'.

$\ddagger$ At least one swollen sperm head per oocyte.

\$ Guinea-pig IgG anti-dinitrophenylated bovine gammaglobulin (control).

Significantly different from control values: ${ }^{*} 0.05<P<0.02 ;{ }^{* *} P<0.01\left(\chi^{2}\right.$ test).

Table 4. Percentage of cleaved eggs recovered from the oviduct of guinea-pigs immunized with sperm autoantigens $\mathrm{S}, \mathrm{P}$ and $\mathrm{T}$

\begin{tabular}{lccc}
\hline $\begin{array}{l}\text { Immunizing } \\
\text { antigen }\end{array}$ & No. of animals & $\begin{array}{c}\text { Collected } \\
\text { eggs } \\
(n)\end{array}$ & $\begin{array}{c}\text { Cleaved } \\
\text { eggs } \\
(\%)\end{array}$ \\
\hline $\begin{array}{l}\text { Splenic cells } \\
\text { (control) }\end{array}$ & 7 & 18 & 89.0 \\
S antigen & 5 & 16 & 93.8 \\
P antigen & 6 & 15 & $33.3^{*}$ \\
T antigen & 7 & 20 & 70.0 \\
\hline
\end{tabular}

Significantly different from control values: $P<0.001\left(\chi^{2}\right.$ test $)$.

inhibit the penetration of intact oocytes. A significant reduction of the number of penetrated zonafree oocytes was observed with $1 \mathrm{mg}$ anti-P IgG/ml and $250 \mu \mathrm{g}$ anti-T $\mathrm{IgG} / \mathrm{ml}$. The penetration was completely inhibited with $500 \mu \mathrm{g}$ anti-T $\mathrm{IgG} / \mathrm{ml}$.

Anti-T IgG Fab at $200 \mu \mathrm{g} / \mathrm{ml}$ reduced the incidence of sperm penetration into zona-free oocytes ( $57 \%$ as compared to $100 \%$ with anti-anti-DNP-BGG IgG Fab).

In all experiments sperm survival and motility were good.

\section{Possible relevance in vivo of the effects observed with in-vitro fertilization}

To test whether anti-P or anti-T and eventually anti-S antibodies could play a role in fertilization in vivo, guinea-pig females were immunized as previously described (De Almeida \& Voisin, $1979)$ with the corresponding antigens or with guinea-pig splenic cells as control. All experimental animals presented high circulating antibody titres in the ELISA test $\left(3 \times 10^{3}\right.$ for $\mathrm{S} ;>3 \times 10^{4}$ for 
$\mathrm{T}$ and $>6 \times 10^{4}$ for $\mathrm{P}$ ) at the time they were mated to proven fertile males. Females were killed $72 \mathrm{~h}$ after mating and oviducts were flushed with 1-2 $\mathrm{ml}$ PBS. The number of cleaved and uncleaved eggs was recorded and the perfusion solution was centrifuged and tested in ELISA with S, P and T antigens. As shown in Table 4 there was a significant decrease $(P<0.001)$ of the number of cleaved eggs recovered from the oviducts of females immunized with $P$ antigen. The percentage fertilization recorded for animals immunized with $\mathrm{T}$ antigen was not statistically different from that of the control group. However, if the percentage for $\mathrm{T}$-antigen-treated animals was compared with that for the S-antigen-treated + control animals the difference became significant $(0.02>P>0.01)$. Antibody activity in tubal washings was very low in S-immunized animals as compared to P- and T-immunized females (data not shown).

\section{Discussion}

The results presented here show that the guinea-pig sperm autoantigens $\mathbf{P}$ and $\mathrm{T}$ are differently involved in two steps of in-vitro fertilization, binding to the zona pellucida and oocyte penetration. The $\mathrm{S}$ antigen apparently does not play a role in these events as judged by antibody-inhibition.

The interaction of acrosome-reacted spermatozoa with the zona involves the inner acrosomal membrane and the sperm plasma membrane over the equatorial segment and the post-acrosomal region (Yanigimachi, 1977). The three antigens studied here were likely candidates for a role in this step of the fertilization process, as they are all present on the inner acrosomal membrane of guineapig acrosome-reacted spermatozoa (Marquant-Le Guienne \& De Almeida, 1986). In fact only anti- $T$ antibodies inhibited sperm binding to the zona. It must be stressed that $T$ antigen, a family of several membrane glycoproteins (Tiffoche, Kanellopoulos \& Voisin, 1985), is localized over the whole plasma membrane of spermatozoa, even after the acrosome reaction. Which $\mathbf{T}$ antigenic molecule(s) is (are) responsible for zona binding cannot be answered without further analysis.

Anti-P antibodies prevent sperm penetration in intact oocytes and to a lesser degree in zona-free oocytes. This ability to block fertilization operates apparently at the stage of binding and/or fusion with the oocyte plasma membrane. This is true also for anti-T antibodies which affected significantly sperm penetration in zona-free oocytes. However, the fact that anti-P antibodies are more inhibitory of egg penetration in the presence than in the absence of the zona pellucida (sperm fixation to the zona pellucida is not prevented) suggests that the $\mathbf{P}$ antigen may play a role during passage through the zona pellucida. There is some immunological evidence that binding to the zona and its penetration are independent events which involve different sperm components ( $O$ 'Rand, 1981).

The blockage of in-vitro fertilization, at least by anti-T antibodies, apparently reflects a specific masking of molecules involved in sperm-oocyte interactions as the Fab fragments of these antibodies still remain capable of inhibiting the same events.

These in-vitro studies indicate that $\mathbf{T}$ and $\mathbf{P}$ sperm antigens may have essential functions in the reproductive process. When female guinea-pigs were immunized with these antigens, fertilization, as judged by the percentage of tubal cleaved eggs, was significantly affected only by $\mathbf{P}$ immunization. There is a parallel between these results and the delayed overall fertility previously observed in female guinea-pigs immunized with the same antigen (De Almeida \& Voisin, 1979). The in-vivo effectiveness of $\mathbf{P}$ immunization may be related to a higher immunogenicity of this antigen as high concentrations of anti-P antibodies were found in tubal washings.

It can be concluded that antibodies against defined sperm antigens, as described here, offer an interesting approach to elucidate the molecular events leading to fertilization. Further progress requires purification of the antigenic preparations and the use of monoclonal antibodies for the analysis of their biological roles.

We thank Professor Ch. Thibault for scientific advice and critical reading of the manuscript; L. Garry and J. Beauquentin for help with the animals; M. Sorgue for typing the manuscript. 


\section{References}

Bertalanfly, F.D. (1962) Evaluation of the acridine orange microscope method for cytodiagnosis of Cancer. Ann. N.Y. Acad. Sci. 93, 715-750.

Bradford, M.M. (1976) A rapid and sensitive method for the quantitation of microgram quantities of protein utilizing the principle of protein dye-binding. Analyt. Biochem. 72, 248-254.

De Almeida, M. \& Voisin, G.A. (1979) Resistance of female guinea pig fertility to efficient iso-immunization with spermatozoa antigens. J. Reprod. Immunol. 1, 237-247.

Le Bouteiller, P., Toullet, F., Righenzi, S. \& Voisin, G.A. (1979) Ultrastructural localization of guinea pig spermatozoal autoantigens on germinal cells by immunoperoxidase techniques. J. Histoch. Cytochem. 27, 857-866.

Marquant-Le Guienne, B. \& De Almeida, M. (1986) Role of guinea-pig sperm autoantigens in capacitation and the acrosome reaction. $J$. Reprod. Fert. 77, 337-345.

O'Rand, M.G. (1981) Inhibition of fertility and sperm zona binding by anti-serum to the rabbit sperm membrane auto-antigen RSA-1. Biol. Reprod. 25, $621-628$.

Tiffoche, C., Kanellopoulos, J. \& Voisin, G.A. (1985) Solubilization and characterization of guinea-pig spermatozoal plasma membrane $\mathrm{T}$ auto-antigen. Fedn Proc. Fedn Am. Socs exp. Biol. 44, 959, Abstr.

Toullet, F. \& Voisin, G.A. (1974) Spermotoxic, spermagglutinating and cytotoxic activities of guinea pig autoantibodies to sperm autoantigen T. J. Reprod. Fert. 37, 299-313.
Toullet, F. \& Voisin, G.A. (1976) Passive transfer of autoimmune aspermatogenic orchiepididymitis by antispermatozoa sera. Clin. exp. Immunol. 26, 549-562.

Toullet, F., Voisin, G.A. \& Nemirovsky, M. (1973) Histochemical localization of three guinea pig spermatozoa autoantigens. Immunology 24, 635-653.

Toullet, F., Chadenier, F., Maillard, J.L. \& Voisin, G.A. (1985) Cellular transfer of auto-immune aspermatogenic-orchiepididymitis by the i.v. route in the guinea pig. Clin. exp. Immunol. 59, 593-603.

Tung, K.S.K., Okada, A. \& Yanagimachi, R. (1980) Sperm autoantigens and fertilization. I. Effects of antisperm autoantibodies on rouleaux formation, viability and acrosome reaction of guinea pig spermatozoa. Biol. Reprod. 23, 877-886.

Voisin, G.A. \& Toullet, F. (1968) Etude sur l'orchite aspermatogénétique autoimmune et les autoantigènes de spermatozoïdes chez le cobaye. Annls Inst. Pasteur 114, 727-755.

Yanagimachi, R. (1977) Specificity of sperm egg interaction. In Immunobiology of the Gametes, pp. 255-289. Eds M. Edidin \& M. H. Johnson. Cambridge University Press.

Yanagimachi, R., Okada, A. \& Tung, K.S.K. (1981) Sperm autoantigens and fertilization. II-Effects of anti-guinea pig sperm autoantibodies on spermovum interactions. Biol. Reprod. 24, 512-518.

Received 22 July 1985 